The presentation of the research projects from sixteen departments at the college was as varied as the subject matter itself. Some departments, like mechanical engineering and physics, wisely chose to concentrate on a few of their notable achievements. The biomedical work in the Mechanical Engineering Department is a good example of the trend to interdisciplinary work; experiments on tensile, fatigue and impact properties of bone joints were on display. Another promising project in this department is the technique of semicontinuous extrusion of metals, in which, by using a lubricant, it is possible to extrude rods or wires virtually continuously.

The Royal School of Mines, also part of Imperial College, had a well illustrated exhibition of geological and mining work, including a description of measurements of crustal movement around the mid-Atlantic ridge. The Metallurgy Department, which has a special interest ranging from nucleation studies of solidifying slags to the properties of thin films and semiconductors, drew attention to the notable decision of the Science Research Council to provide the first million volt electron microscope in the department, which should be operating later this year.

The Chemical Engineering Department is investigating the transport of solids using fluidization with air. This could have applications in mining and factory processes. Work of great practical relevance on pollution and aerosols is also in progress, in particular to study the properties of sulphur dioxide which is a major industrial pollutant.

Techniques for studying photosynthesis in intact tomato plants were among the exhibits in the Department of Botany and Plant Technology. The mechanism of photosynthesis in crop plants is being investigated with the long term objective of increasing yields. The Chemistry Department, still buried in outdated surroundings, is in urgent need of removal to the new building which is still under construction. The new equipment which the department has acquired for the study of molecular structures seems to cry out for congenial working conditions.

\section{ENGINEERING TRADE}

\section{Gzech Doors Open}

The new Czechoslovak Embassy in London has been the scene during the past week of the first Czechoslovak Engineering and Technical Days. National weeks of one description or another have become a fashionable and on the whole successful way of publicizing a particular national cause, and this Czechoslovak week was organized to present to British industry the technical information about Czechoslovak industry that is considered vital for the expansion of AngloCzech trade.

Opening the proceedings, which consisted of five days of lectures on various sectors of Czechoslovak industry, Dr Miloslav Rusek, the Czech Ambassador to the United Kingdom, said that it was the aim of Czechoslovakia to increase its trade with Western Europe. He thought that there was a distinct lack of knowledge about engineering industry in Czechoslovakia, and that even arranging this week of lectures had helped to catalyse trade in this field.

Lord Erroll, president of the London Chamber of
Commerce, and Mr John Davies, director general of the Confederation of British Industry, both welcomed the initiative which led to last week's gathering. Lord Erroll mentioned that the London Chamber of Commerce had been active in promoting similar British events in Czechoslovakia - there have been five since 1965.

Mr Ludvik Ubl, Minister of State at the Czechoslovak Ministry of Foreign Trade, said that trade between Britain and Czechoslovakia stood at $£ 16$ million last year, and he thought the recent restructuring of Czech industry would make it more conducive to foreign trade. He said that British industry had made a significant impression in Czechoslovakia with chemical plants, computers and ships.

\section{MEDICAL RESEARCH \\ Artificial limbs}

A NEW research unit to investigate physical aids for the disabled is to be set up in Edinburgh by the Medical Research Council. The intention is that the unit, under the direction of Dr D. C. Simpson, who has been seconded to the MRC, should complement and extend the work being carried out in the Orthopaedic BioEngineering Unit at the Princess Margaret Rose Orthopaedic Hospital, which Dr Simpson also directs. Work at the Bio-Engineering Unit was confined principally to designing artificial limbs for thalidomide children and it now seems that much of the research should be directly applicable to adults suffering from diseases such as multiple sclerosis or cerebral palsy-this is the direction in which the new MRC unit hopes to move.

Dr Simpson's staff, initially four, will be concerned with three main areas of research-the fundamental analysis of the function and movement of artificial limbs and splints required by a paralysed or limbless patient, particularly in relation to his personal environment; the study of factors relating to the control of aids and of the ways in which positional and tactile information can be incorporated and also the mechanical design of aids, including the actuation systems for externally powered limbs.

A spokesman for the MRC estimates that the building cost and running costs for the first year will amount to about $£ 40,000$.

\section{AGRICULTURE Institute Institutionalized}

The National Institute of Agricultural Botany is to retain its independence. It will not become a scientific institute within the Ministry of Agriculture, staffed by civil servants, as a joint review group from the institute and the ministry proposed in January last year. $\mathrm{Mr}$ Cledwyn Hughes, Minister of Agriculture, gave the news on May 12 in a written reply to Mr Tudor Watkins who asked whether a decision had been reached about the future of the institute.

The need for changes at NIAB arose as a consequence of the Plant Varieties Act of 1964, which gave plant breeders rights to control by licence the sale and reproduction of their own varieties. The act made provision for an index of varieties to be set up, and for 